\title{
Artificial Intelligence a Revolution for HR in Talent Management in IT Sector
}

\author{
Reena (Mahapatra) Lenka, Anand B. Dadas
}

\begin{abstract}
This research paper is based on the idea that artificial intelligence can do wonders for the HR sector of the company in terms of Talent Management. People tend to have a wrong notion of artificial intelligence being a threat to human beings in terms of jobs. This is not true as it is mankind who has created machines and not vice versa. This research will help clear out the fear in people's mind in terms of artificial intelligence and would prove that artificial intelligence is such a revolution for human being and when handled properly, can prove to be a boon for HRM. In today's world most of the IT companies are multinational, fully automated and undergo constant technology change and the work force is of distinct cultures and diverse mindsets. It becomes difficult for the HR Manager to cope up with so much change and go for effective Talent Management. Through artificial intelligence HR Manager can have help in developing effective Talent Management in terms of Talent Acquisition, Performance Management, Career Development and Retention of employees and this in turn would lead to employee satisfaction and employee motivation which is critical in the IT sector. The IT sector workers undergo so much work-related stress that it is the need of the hour that their morale should be always boosted. This can be achieved when artificial intelligence joins hands with $H R$.

Keywords: Talent Acquisition, Performance Management, Career development and Retention
\end{abstract}

\section{INTRODUCTION}

Artificial intelligence is nothing new. Historically, humans are fascinated with the idea of how machines can behave and work like humans. This concept gave birth to artificial intelligence. John McCarthy is one of the "founding fathers" of artificial intelligence, together with Alan Turing, Marvin Minsky, Allen Newell, and Herbert A. Simon. McCarthy coined the term "Artificial Intelligence" in 1955 and organized the famous Dartmouth conference in Summer 1956. This conference started AI as a field. He developed the Lisp programming language family, significantly influenced the design of the ALGOL programming language, popularized timesharing, and was very influential in the early development of AI. In short, artificial intelligence is nothing but intelligent machines that can work and react like humans.

\section{- Meaning of Artificial Intelligence}

Revised Manuscript Received on March 2, 2020.

Dr. Reena (Mahapatra) Lenka, Assistant Professor, MIT-DET Univeristy,prof.reenalenka@gmail.com

Dr. Anand B. Dadas, Director and Professor, Neville Wadia Institute of Management Studies \& Research,Pune, drdadas.10@gmail.com
Artificial Intelligence, according to the English Oxford Living Dictionary is: "The theory and development of computer systems able to perform tasks normally requiring human intelligence, such as visual perception, speech recognition, decision-making, and translation between languages". Merriam-Webster defines is it as "the ability of a machine to imitate intelligent human behavior" and the Encyclopedia Britannica defines it as "the ability of a digital computer or computer-controlled robot to perform tasks commonly associated with intelligent beings". Simply put Artificial intelligence is the ability of machines to think and work like human beings. This is possible by the help of two technologies- Machine Learning and Deep Learning

\section{- Importance of Machine Learning\& Deep Learning}

Machine learning is a branch of artificial intelligence that helps machines learn and make predictions with respect to data. This type of machine learning is possible through pattern recognition and algorithms. For example, an algorithm that wants to identify bus will depend on images of other buses to educate itself regarding how a bus looks like. In this case the final destination is clear- to identify a bus, but in order to arrive to this final destination the machine has to take help from the data. Deep learning or deep neural learning is a branch of artificial intelligence that with the help of data and patterns functions in the same way as a human brain in decision making. Deep learning is basically a part of machine learning in artificial intelligence that by use of networks has the ability to learn independently from unstructured data.

- Uses of Machine Learning in Talent Management

- Talent Management

Talent management is the process of finding vacant positions, hiring the right personnel, developing the person skills according to the required positions and ensuring that the person is retained for an optimum period to meet the individual's and organization's long-term goals.

Talent Management Process Model 


\section{Artificial Intelligence a Revolution for HR in Talent Management in IT Sector}

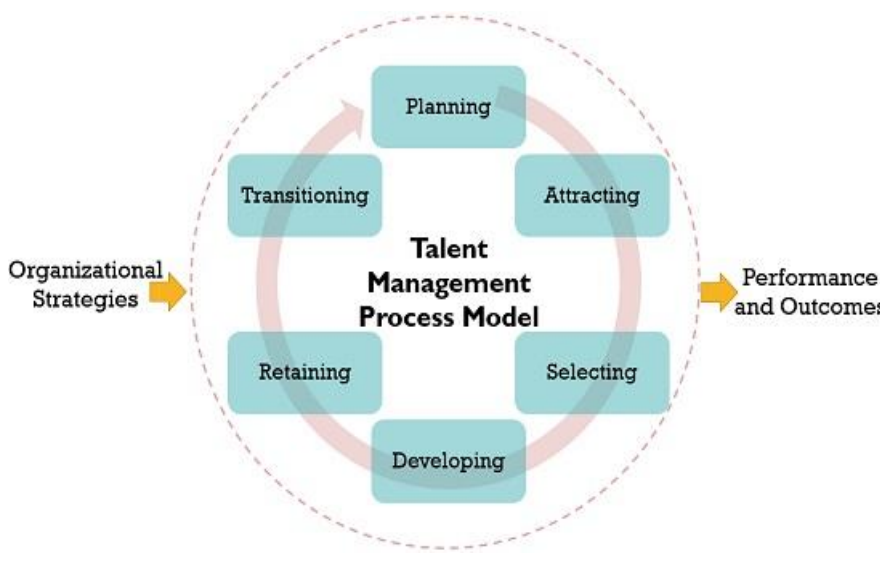

- Role of Artificial Intelligence in Effective Talent Management

In recent years there have been growing concerns about machines taking over humanity. People also fear that machines are going to seize jobs and people would be left unemployed. In order to overcome this concern, Artificial intelligence with a human touch is the need of the hour. With human collaboration, the machines are becoming much more human friendly and are able to take care of the needs of humankind in a much better way.

The advent of artificial intelligence is a boon for the Human Resources department. Today artificial intelligent is prevalent in every sector ranging from IT, Automobiles, Aviation, Health and Medicine, Education to name a few. The sector which needs artificial intelligence the most is Human resource sector. The reason being people are so complicated that it is not easy for a Human Resources Manager to deal with human workforce. In this case Artificial intelligence works as a helping hand for the HR Manager.

\section{- Importance of AI in Talent Management}

According to Ted Greenwald- "Artificial intelligence is changing the way managers do their job from who gets hired to how they're evaluated to who gets promoted."- From the above lines it is clear that in today's world artificial intelligence can play a big role in talent acquisition and help HR managers to decide whom to hire and also keep a track of the performance appraisal and growth of employees which in return can solve most of the HR related issues faced by us time and again. The areas of Talent Management where Artificial intelligence can contribute are the following:

\section{- Talent Acquisition and Retention of Employees}

An enterprise can strive and work efficiently if only it has a good talent pool available. Nowadays people have become so street smart that they can go to any extent to prove that they are right for a position. With so many candidates applying for a profile it becomes very difficult for a HR Manager to find out the exact fit for a position. Here HR Manager with the help of Artificial intelligence can scan the entire database and segregate efficiently the required talented $\mathrm{CV}$. Then the HR Manager can take interviews and hire the required person. This way the best person can be placed at the right position. This increases the performance of the person and the employee become happy by contributing to the organization and individual goal. This leads to effective retention of employees.

\section{- Performance Management}

Artificial intelligence contributes to HRM by cutting short the cyclical work of the HR Manager like screening of CV's, sourcing talent. This helps the HR Manager to have enough time to investigate the employee's developmental aspects within the company. Performance management is an important aspect of talent management. The right person at the right place through the help of artificial intelligence helps the person to perform better and better. Artificial Intelligence also contributes by screening through the existing employee data as well and lets the HR Manager know regarding the talent of the existing employee. The HR Manager in return having enough time can keep a track of the performance of the person and reward the employees by effective performance appraisal and this leads to employee satisfaction, retention and in return contribute to efficient talent management.

\section{- Career Path Development}

Artificial intelligence helps in career path planning for employees. Records say that the newer generation does not stick to a single job for a longer time. They have a tendency for job hopping. The older generation was more stable compared to today's generation. The company always wants that people don't leave their job but if they want they can change from one position to another within the company. Artificial intelligence helps here by planning for the employee depending on his or her preference and aspirations so that the person starts growing within the company and does not want to leave the company as his individual goal is met. Artificial intelligence also helps the HR Manager to plan the career for a person's future as well by providing the screened data so that the employees understand what exactly the person wants according to his or her preferences. The HR Manager in return helps so that the employee's present and future aspirations are taken care of and the employee grows as well as the company grows, and talent is retained.

\section{REVIEW LITERATURE}

"Talent acquisition through technology" acquiring best talent in the organization is very important. The paper Intelligent automation (Dr. Aruna Deshpande, 2018)states that artificial intelligence can be used in the following ways:

\section{- AI Recruiting Assistants}

This software communicates with the candidate automatically and saves lots of time of the HR.

Intelligent recruitment software: AI screening tools tries to understand the requirement of the company, screens the data, then selects the best candidate to be interviewed and informs the HR Manager so that the recruitment process goes very successfully, and the best person is hired.

\section{- Digitized Interviews}

AI analyses and understands the digitization 
process of interviews like video interviews. It then through analyzation of the requirement finds the perfect fit and arranges for the interview depending on the person's job preferences and expectations.

"The Impact of artificial intelligence in Talent acquisition lifecycle of Organizations a Global perspective" (Dr. Saundarya Rajesh, Mr. Umasanker Kandaswamy and Ms. Anju Rakesh 2018). The paper sheds light on a LinkedIn report (2017) on global recruitment trends stressing that hiring in companies should be automated. This took the world by storm. This finding stated that screening and hiring will be fully automated throughout the world in order to remove biases in terms of caste, country, language, sex etc. and will give enough time to the HR for other activities. This automation will lead to increase in recruitment volume. This paper also discusses how AI is helpful in every stage of Talent management process from screening, recruitment, performance management, retention and career planning.

"Innovation is a process of industrial mutation that incessantly revolutionizes the economic structure from within, destroying the old one and incessantly creating the new one" (Sledzik, 2013). The paper states that innovations force the companies to plan for inclusion of artificial intelligence in the companies by changing its economic structures. It further goes on to explain how innovations can create a framework for adaptation of artificial intelligence in companies.

"Recruitment through artificial intelligence- A conceptual study"(Geetha R and BhanuSree Reddy D). The paper states that effective recruitment is a part of talent management. Effective recruitment is very essential for the growth of the company. Without proper recruitment it is very difficult for any organization to survive. This paper throws light on the fact that artificial intelligence can help any organization to locate and recruit the best talent in the organization.

\section{Limitations}

1. The study is limited only to the multinational IT companies based in Pune- India- as the author is located in Pune.

2. The paper is based only on multinational IT sectors in Pune as artificial intelligence is generally widely used in IT sectors.

3. The article is limited only to $56 \mathrm{HR}$ mangers in multinational IT companies in Pune- India as these 56 companies are the topmost multinational companies who are using artificial intelligence widely in their organization.

\section{Objective}

1. To explore and understand the importance of artificial intelligence in talent acquisition and retention of the employees in organization

2. To identify and critically analyze the contribution of artificial intelligence with respect to performance management and career path development of the employees.
3. To understand the challenges involved in proving that artificial intelligences a boon for HR managers in terms of Talent management and recommend solutions for the same.

\section{Hypothesis}

1. $\mathrm{H} 0=$ Artificial Intelligence is not a boon for $\mathrm{HR}$ managers with respect to Talent Management.

$\mathrm{H} 1=$ Artificial Intelligence is a boon for HR managers with respect to Talent Management

2. $\mathrm{H} 0=$ Artificial Intelligence cannot contribute in effective career path development of the employees in an organization

$\mathrm{H} 1=$ Artificial intelligence can contribute effectively in career path development of the employees in an organization

3. $\mathrm{H} 0=$ Artificial intelligence cannot help in employee engagement engagement

$\mathrm{H} 1=$ Artificial intelligence can help in employee

\section{RESEARCH METHODOLOGY}

The descriptive research design adopted to test hypothesis and exploratory research helped to formulate objectives, hypothesis and variables of this research. Hence, practically this research is mixed research design of exploratory and descriptive methods. The purposive sampling technique is used to select $56 \mathrm{HR}$ manager respondents from IT companies all around Pune city. The survey was conducted using Google forms with close ended Nominal and Likert scale questions. The questionnaire was based on 3 elements of Talent management such as talent acquisition, performance management and career path development. Computer tools like SPSS and MS-Excel were used for data analysis and statistical hypothesis testing.

\section{DATA ANALYSIS}

The data collected is processed through SPSS software to estimate the relationships among variables considered for research study. The conclusions to justify the objectives and test the hypothetical relationships are drawn as mentioned below:

\section{Reliability of Research Instrument}

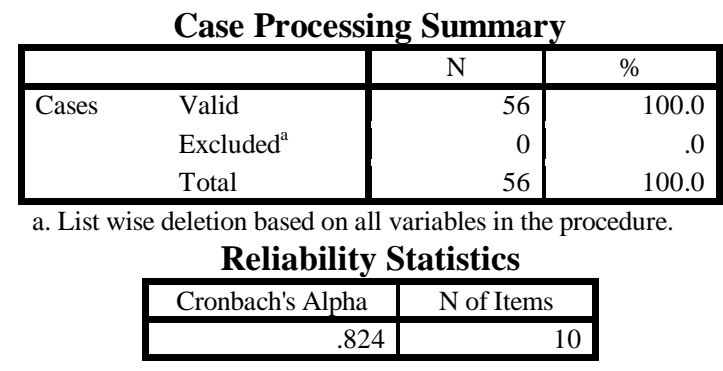




\section{Artificial Intelligence a Revolution for HR in Talent Management in IT Sector}

\section{Observation:}

The Cronbach's Alpha value is found 0.824 which is in accepted range and justify the $82.4 \%$ capacity of research instrument to measure the HR manager's perspective towards Artificial Intelligence as a revolution for $\mathrm{HR}$ in Talent Management.

\section{Descriptive Data Analysis}

Following are some interpretations of descriptive analysis

1. Companies are using moderate artificial intelligence for human capital management. According to $45.8 \%$ HR managers; $16.7 \%$ managers are saying that they use high intensity artificial intelligence followed by $10.4 \%$ using low level artificial intelligence for HR management.

2. $13.6 \%$ HR managers strongly agreed that today's HR is acknowledgeable followed by $18.2 \%$ agreed the same. Most of the HR managers are neutral in opinion about the acknowledgement of HR for enhancement of talent management.

3. Out of total employees' $27.3 \%$ have strongly agreed and $36.4 \%$ have agreed that Artificial Intelligence can be an effective tool in talent acquisition based on job description, education and locality whereas rest HR managers do not consider artificial intelligence useful for talent acquisition.

4. $15.9 \%$ HR managers strongly and $34.1 \%$ moderately thinks that Artificial Intelligence can recommend best candidates for interview whereas $38.6 \% \mathrm{HR}$ managers are neural in opinion about the same.
5. $25 \% \mathrm{HR}$ manages are strongly agreed and $43.2 \%$ are agreed that Artificial Intelligence is competent enough in automating screening and reduce human bias during interviews. $15 \% \mathrm{HR}$ managers are neutral and $13.6 \%$ are disagreed about this statement.

6. $43.2 \%$ HR managers are neutral, $18.2 \%$ are strongly agreed and $25 \%$ agreed that artificial intelligence is being used in their company to automatically engage the with candidates in terms of chat bots and messaging.

7. $52.3 \%$ HR managers think that artificial intelligence can help in guiding new recruiters through company policies followed by $18.2 \%$ agreeing the statement. $20.5 \%$ HR managers are neutral about the statement followed by rest respondents disarraying the use of artificial intelligence for guiding HR managers.

8. $25 \%$ HR managers strongly agreed and $40.9 \%$ agreed that Artificial Intelligence can be the effective tool for performance management through timely performance appraisal. $27.3 \% \mathrm{HR}$ managers are negative opinion for the use of artificial intelligence in these two functions.

9. Almost $70 \%$ HR managers thinks that artificial intelligence is helping in improving work place learning of employees whereas rest are negative about that.

10. $80 \%$ of respondents think that artificial intelligence helps HR managers in effective career path development for employees.

\section{Hypothesis Testing}

H0= Artificial Intelligence is not a boon for HR managers with respect to Talent Management.

Test of correlation is used to estimate the relationship between the applicability of artificial intelligence in talent management.

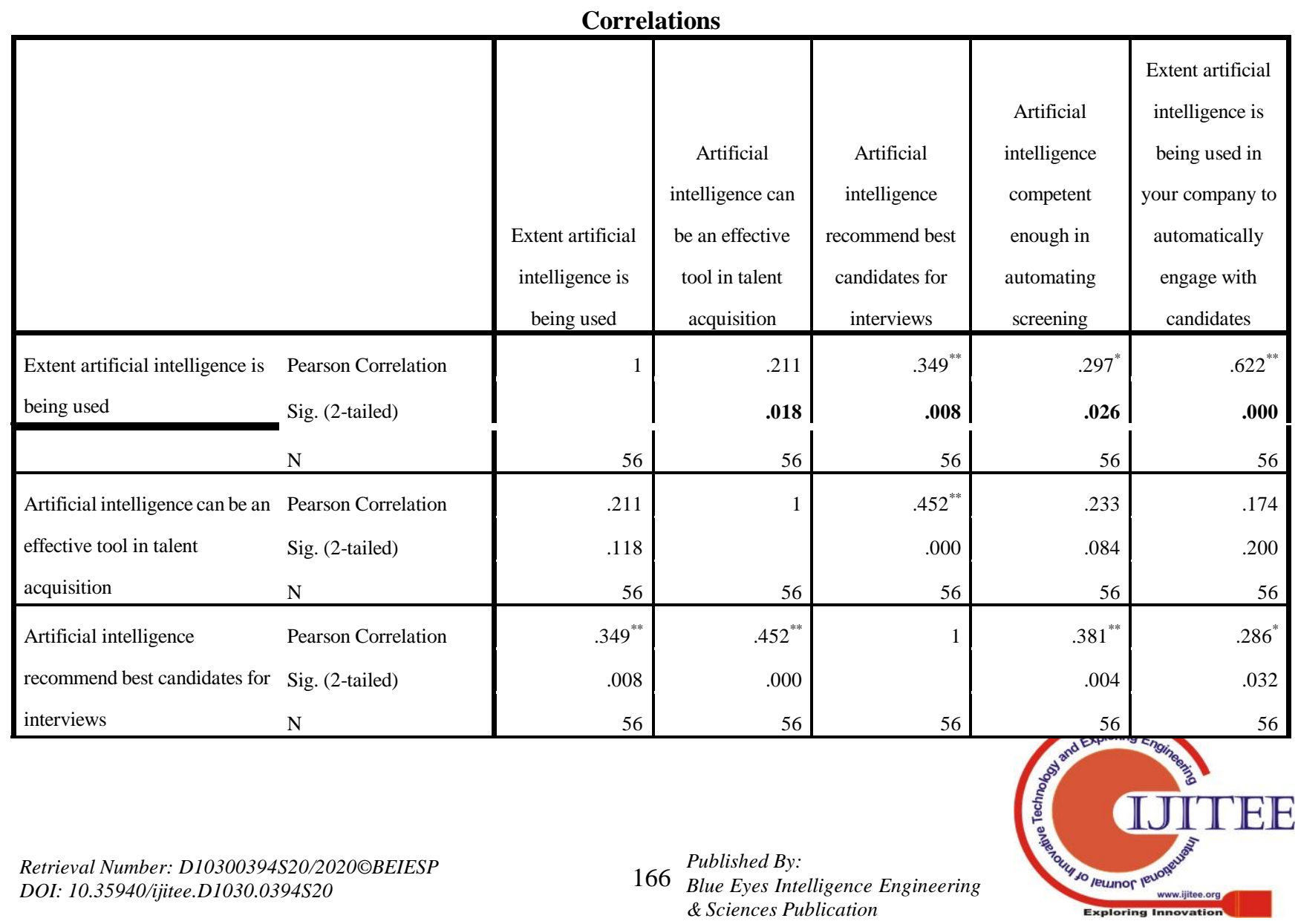


International Journal of Innovative Technology and Exploring Engineering (IJITEE) ISSN: 2278-3075, Volume-9 Issue-4S, March 2020

\begin{tabular}{|ll|r|r|r|r|}
\hline Artificial intelligence & Pearson Correlation & $.297^{*}$ & .233 & $.381^{* *}$ \\
competent enough in & Sig. (2-tailed) & .026 & .084 & .200 \\
automating screening & $\mathrm{N}$ & 56 & .004 \\
\hline $\begin{array}{l}\text { Extent artificial intelligence is } \\
\text { being used in your company to }\end{array}$ & Sig. (2-tailed) & $.622^{* *}$ & .174 & .139 \\
automatically engage with & $\mathrm{N}$ & .000 & .200 & $.286^{*}$ \\
candidates & 56 & 56 & .032 \\
\hline
\end{tabular}

**. Correlation is significant at the 0.01 level (2-tailed).

*. Correlation is significant at the 0.05 level (2-tailed).

Observation: Significant correlation values as highlighted in correlation table justifies rejection of null hypothesis.

\begin{tabular}{|c|c|c|c|c|c|c|}
\hline \multicolumn{7}{|c|}{ Correlations } \\
\hline & & $\begin{array}{c}\text { Extent artificial } \\
\text { intelligence is } \\
\text { being used }\end{array}$ & $\begin{array}{l}\text { Artificial } \\
\text { intelligence help } \\
\text { in guiding new } \\
\text { recruits }\end{array}$ & $\begin{array}{c}\text { Artificial } \\
\text { intelligence can } \\
\text { be a tool for HR } \\
\text { managers for } \\
\text { effective } \\
\text { performance } \\
\text { management }\end{array}$ & $\begin{array}{c}\text { Artificial } \\
\text { intelligence } \\
\text { helping HR } \\
\text { managers in } \\
\text { improving work } \\
\text { place learning of } \\
\text { employees }\end{array}$ & $\begin{array}{c}\text { Artificial } \\
\text { intelligence help } \\
\text { HR managers in } \\
\text { effective career } \\
\text { path } \\
\text { development for } \\
\text { employees }\end{array}$ \\
\hline $\begin{array}{l}\text { Extent artificial intelligence is } \\
\text { being used }\end{array}$ & $\begin{array}{l}\text { Pearson Correlation } \\
\text { Sig. (2-tailed) } \\
\mathrm{N}\end{array}$ & $\begin{array}{r}1 \\
56 \\
\end{array}$ & $\begin{array}{r}.189 \\
.014 \\
56 \\
\end{array}$ & $\begin{array}{r}.318^{*} \\
.017 \\
56 \\
\end{array}$ & $\begin{array}{r}.331^{*} \\
.013 \\
56 \\
\end{array}$ & $\begin{array}{r}.348^{* *} \\
.009 \\
56 \\
\end{array}$ \\
\hline $\begin{array}{l}\text { Artificial intelligence help in } \\
\text { guiding new recruits }\end{array}$ & $\begin{array}{l}\text { Pearson Correlation } \\
\text { Sig. (2-tailed) } \\
\mathrm{N}\end{array}$ & $\begin{array}{r}.189 \\
.164 \\
56 \\
\end{array}$ & $\begin{array}{r}1 \\
56 \\
\end{array}$ & $\begin{array}{r}.626^{* *} \\
.000 \\
56 \\
\end{array}$ & $\begin{array}{r}.490^{* *} \\
.000 \\
56 \\
\end{array}$ & $\begin{array}{r}.686^{* *} \\
.000 \\
56 \\
\end{array}$ \\
\hline $\begin{array}{l}\text { Artificial intelligence can be a } \\
\text { tool for HR managers for } \\
\text { effective performance } \\
\text { management }\end{array}$ & $\begin{array}{l}\text { Pearson Correlation } \\
\text { Sig. (2-tailed) } \\
\text { N }\end{array}$ & $\begin{array}{r}.318^{*} \\
.017 \\
56\end{array}$ & $\begin{array}{r}.626^{* *} \\
.000 \\
56\end{array}$ & 1 & $\begin{array}{r}.744^{* *} \\
.000 \\
56\end{array}$ & $\begin{array}{r}.716^{* *} \\
.000 \\
56\end{array}$ \\
\hline $\begin{array}{l}\text { Artificial intelligence helping } \\
\text { HR managers in improving } \\
\text { work place learning of } \\
\text { employees }\end{array}$ & $\begin{array}{l}\text { Pearson Correlation } \\
\text { Sig. (2-tailed) } \\
\text { N }\end{array}$ & $\begin{array}{r}.331^{*} \\
.013 \\
56\end{array}$ & $\begin{array}{r}.490^{* *} \\
.000 \\
56\end{array}$ & $\begin{array}{r}.744^{\text {** }} \\
.000 \\
56\end{array}$ & 1 & $\begin{array}{r}.682^{* *} \\
.000 \\
56\end{array}$ \\
\hline
\end{tabular}

\begin{tabular}{|ll|r|r|r|r|}
\hline Artificial intelligence help HR & Pearson Correlation & $.348^{* *}$ & $.686^{* *}$ & $.716^{* *}$ & $.682^{* *}$ \\
managers in effective career & Sig. (2-tailed) & .009 & .000 & .000 \\
path development for & $\mathrm{N}$ & 56 & 56 & 56 \\
employees & & 56 & 56 \\
\hline
\end{tabular}

*. Correlation is significant at the 0.05 level (2-tailed).

**. Correlation is significant at the 0.01 level (2-tailed). 


\section{Artificial Intelligence a Revolution for HR in Talent Management in IT Sector}

Observation: Significant correlation values as highlighted in correlation table justifies rejection of null hypothesis.

$H 0=$ Artificial Intelligence cannot contribute in effective career path development of the employees in an organization Variables Entered/ Removed ${ }^{\mathrm{b}}$

\begin{tabular}{|l|l|c|l|}
\hline Model & \multicolumn{1}{|c|}{ Variables Entered } & Variables Removed & \multicolumn{1}{|c|}{ Method } \\
\hline 1 & $\begin{array}{l}\text { Extent artificial intelligence is } \\
\text { being used }^{\mathrm{a}}\end{array}$ & & Enter \\
& & & \\
\hline
\end{tabular}

a. All requested variables entered.

b. Dependent Variable: Artificial intelligence help HR managers in effective career path development for employees

\begin{tabular}{|c|c|c|c|c|c|c|c|c|c|c|}
\hline & & & & & el Summ & $\mathbf{y}^{\mathbf{b}}$ & & & & \\
\hline \multirow[t]{2}{*}{ Model } & \multirow[b]{2}{*}{$\mathrm{R}$} & \multirow[b]{2}{*}{ R Square } & \multirow{2}{*}{$\begin{array}{c}\text { Adjusted R } \\
\text { Square }\end{array}$} & \multirow{2}{*}{$\begin{array}{l}\text { Std. Error of } \\
\text { the Estimate }\end{array}$} & \multicolumn{5}{|c|}{ Change Statistics } & \multirow{2}{*}{$\begin{array}{c}\text { Durbin-Watso } \\
n\end{array}$} \\
\hline & & & & & R Square & F Change & df1 & $\mathrm{df} 2$ & Sig. F Change & \\
\hline 1 & $.348^{\mathrm{a}}$ & .121 & .105 & .840 & .121 & 7.455 & 1 & 54 & .009 & 2.310 \\
\hline
\end{tabular}

a. Predictors: (Constant), Extent artificial intelligence is being used

b. Dependent Variable: Artificial intelligence help HR managers in effective career path development for employees

$\operatorname{ANOVA}^{\mathrm{b}}$

\begin{tabular}{|c|c|c|c|c|c|c|}
\hline \multicolumn{2}{|c|}{ Model } & Sum of Squares & df & Mean Square & $\mathrm{F}$ & Sig. \\
\hline \multirow[t]{3}{*}{1} & Regression & 5.260 & 1 & 5.260 & 7.455 & $.009^{\mathrm{a}}$ \\
\hline & Residual & 38.097 & 54 & .706 & & \\
\hline & Total & 43.357 & 55 & & & \\
\hline
\end{tabular}

a. Predictors: (Constant), Extent artificial intelligence is being used

b. Dependent Variable: Artificial intelligence help HR managers in effective career path development for employees

\begin{tabular}{|c|c|c|c|c|c|c|}
\hline \multicolumn{7}{|c|}{ Coefficients $^{\mathrm{a}}$} \\
\hline \multirow{2}{*}{\multicolumn{2}{|c|}{ Model }} & \multicolumn{2}{|c|}{ Unstandardized Coefficients } & Standardized & & \multirow[b]{2}{*}{ Sig. } \\
\hline & & B & Std. Error & Beta & $\mathrm{t}$ & \\
\hline \multirow[t]{3}{*}{1} & (Constant) & 3.061 & .325 & & 9.426 & .000 \\
\hline & Extent artificial intelligence is being & .268 & .098 & .348 & 2.730 & .009 \\
\hline & used & & & & & \\
\hline
\end{tabular}

a. Dependent Variable: Artificial intelligence help HR managers in effective career path development for employees

Residuals Statistics ${ }^{\text {a }}$

\begin{tabular}{|l|r|r|r|r|r|}
\hline & Minimum & Maximum & Mean & Std. Deviation & $\mathrm{N}$ \\
\hline Predicted Value & 3.33 & 4.40 & 3.89 & .309 & 56 \\
Residual & -2.864 & 1.136 & .000 & .832 & 56 \\
Std. Predicted Value & -1.825 & 1.639 & .000 & 1.000 & 56 \\
Std. Residual & -3.410 & 1.352 & .000 & .991 & 56 \\
\hline
\end{tabular}

a. Dependent Variable: Artificial intelligence help HR managers in effective career path development for employees 
Normal P-P Plot of Regression Standardized Residual

\section{Dependent Variable: Artificial intelligence help HR managers in effective career} path development for employees

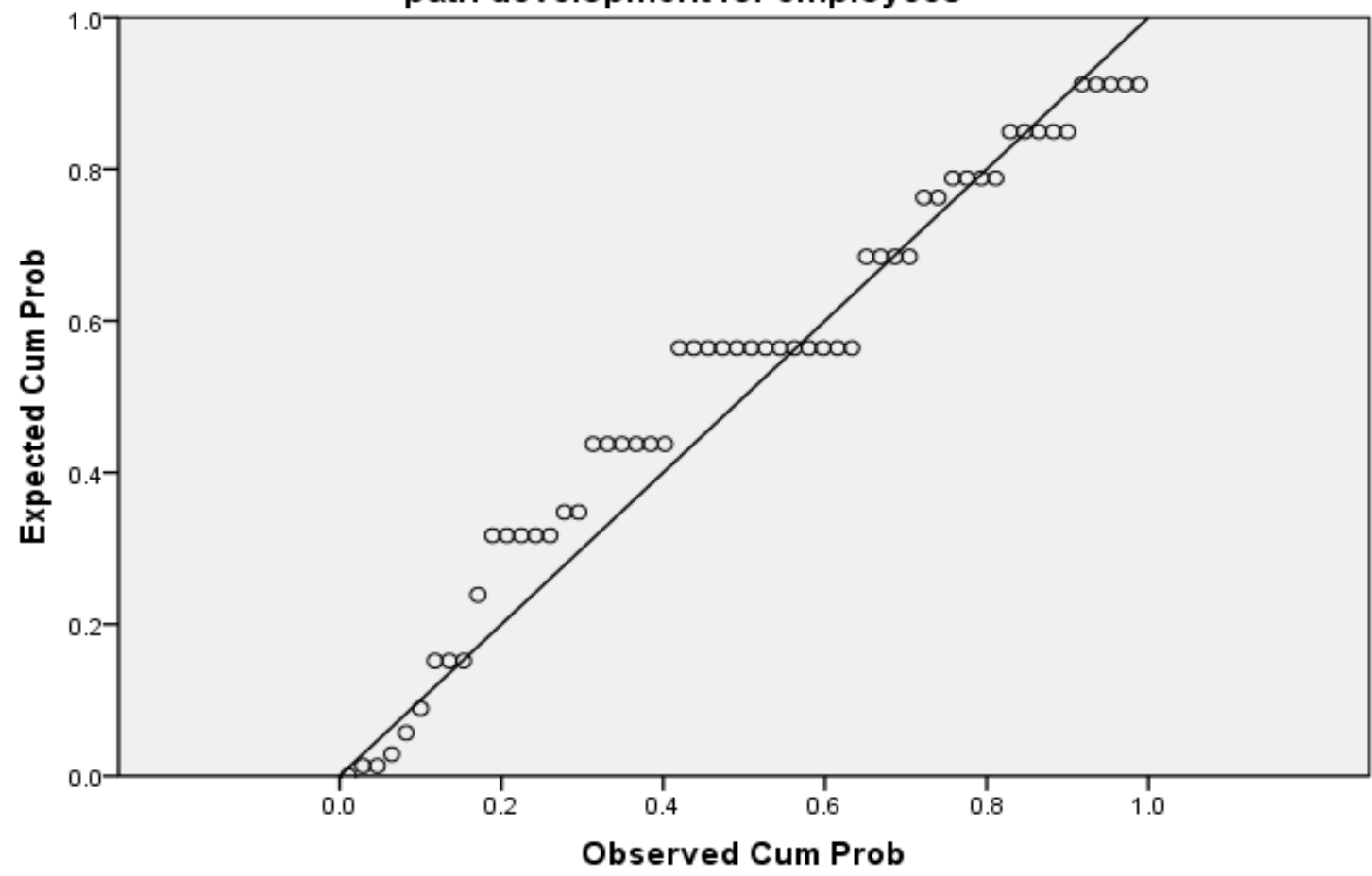

\section{Observation:}

Significant Alpha vale p>0.05 for ANOVA and f-statistics indicates the rejection of null hypothesis which signifies that Artificial intelligence help in employee engagement.

\section{HO= Artificial intelligence cannot help in employee engagement}

This hypothesis describes the relationship between implementation of Artificial Intelligence and its impact on employee engagement. Test of regression is used to estimate the dependency relationship between these variables.

\begin{tabular}{|c|c|c|c|}
\hline \multicolumn{4}{|c|}{ Variables Entered/Removed $^{\text {b }}$} \\
\hline Model & Variables Entered & $\begin{array}{l}\text { Variables } \\
\text { Removed }\end{array}$ & Method \\
\hline c 1 & $\begin{array}{l}\text { Today's HR knowledgeable enough for the usage of artificial intelligence, } \\
\text { Extent artificial intelligence is being used }\end{array}$ & & Enter \\
\hline
\end{tabular}

a. All requested variables entered.

b. Dependent Variable: Extent artificial intelligence is being used in your company to automatically engage with candidates

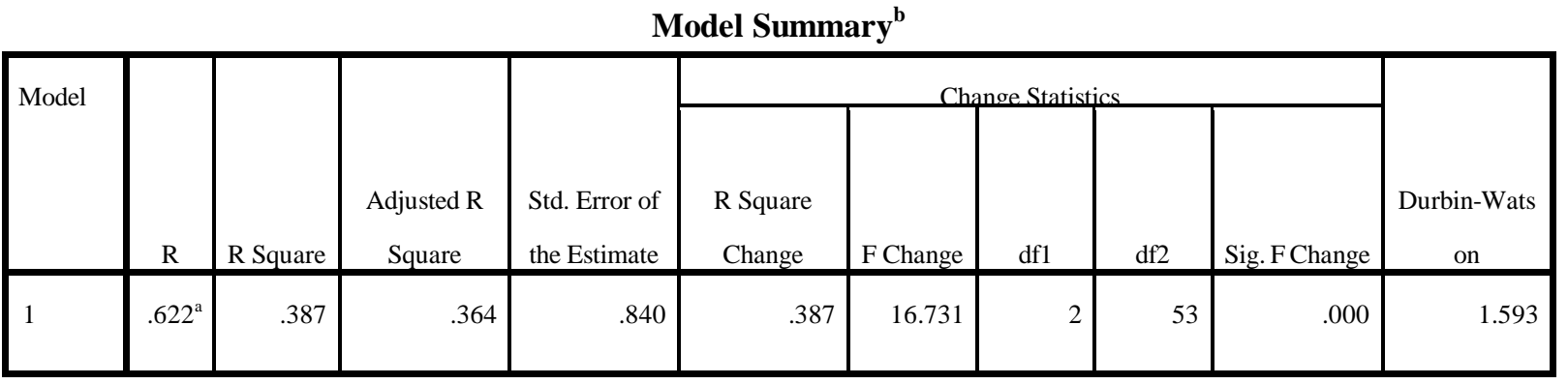

a. Predictors: (Constant), Today's HR knowledgeable enough for the usage of artificial intelligence, Extent artificial intelligence is being used 


\section{Artificial Intelligence a Revolution for HR in Talent Management in IT Sector}

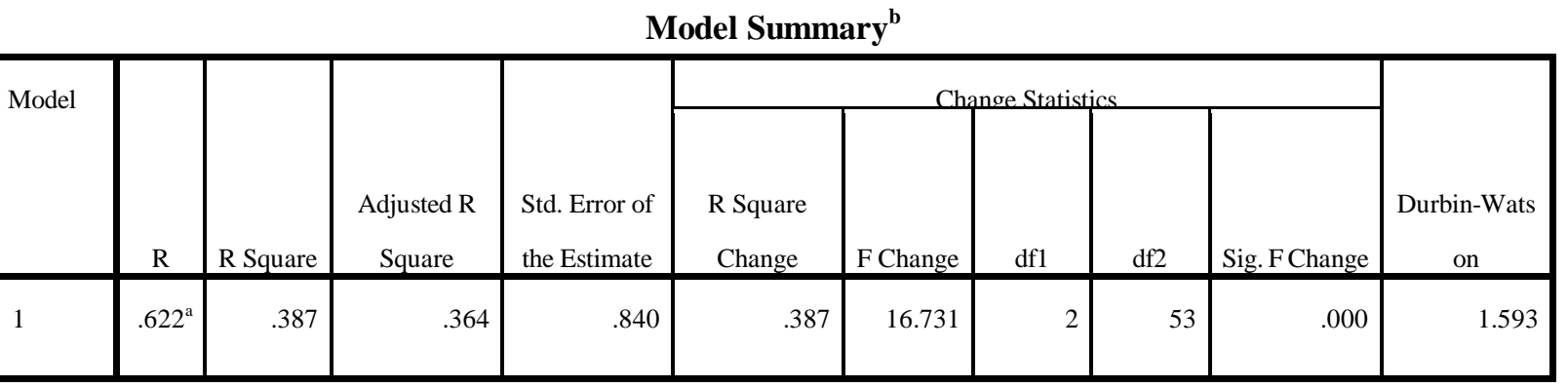

a. Predictors: (Constant), Today's HR knowledgeable enough for the usage of artificial intelligence, Extent artificial intelligence is being used

b. Dependent Variable: Extent artificial intelligence is being used in your company to automatically engage with candidates

\begin{tabular}{|c|c|c|c|c|c|c|}
\hline \multicolumn{7}{|c|}{ ANOVA $^{b}$} \\
\hline & & Sum of Squares & $\mathrm{df}$ & Mean Square & $\mathrm{F}$ & Sig. \\
\hline \multirow[t]{3}{*}{1} & Regression & 23.601 & 2 & 11.801 & 16.731 & $.000^{\mathrm{a}}$ \\
\hline & Residual & 37.381 & 53 & .705 & & \\
\hline & Total & 60.982 & 55 & & & \\
\hline
\end{tabular}

a. Predictors: (Constant), Today's HR knowledgeable enough for the usage of artificial intelligence, Extent artificial intelligence is being used

b. Dependent Variable: Extent artificial intelligence is being used in your company to automatically engage with candidates

\begin{tabular}{|c|c|c|c|c|c|c|}
\hline \multicolumn{7}{|c|}{ Coefficients $^{\mathrm{a}}$} \\
\hline \multirow{2}{*}{\multicolumn{2}{|c|}{ Model }} & \multicolumn{2}{|c|}{ Unstandardized Coefficients } & \multirow{2}{*}{$\begin{array}{l}\text { Standardized } \\
\text { Coefficients } \\
\text { Beta }\end{array}$} & \multirow[b]{2}{*}{$\mathrm{t}$} & \multirow[b]{2}{*}{ Sig. } \\
\hline & & $\mathrm{B}$ & Std. Error & & & \\
\hline \multirow[t]{5}{*}{1} & (Constant) & .956 & .408 & & 2.345 & .023 \\
\hline & Extent artificial intelligence is being & .565 & .109 & 619 & 5.197 & .000 \\
\hline & used & & & & & \\
\hline & Today's HR knowledgeable enough & .007 & .118 & .007 & .056 & .956 \\
\hline & for the usage of artificial intelligence & & & & & \\
\hline
\end{tabular}

a. Dependent Variable: Extent artificial intelligence is being used in your company to automatically engage with candidates

Residuals Statistics ${ }^{\mathrm{a}}$

\begin{tabular}{|c|c|c|c|c|c|}
\hline & Minimum & Maximum & Mean & Std. Deviation & $\mathrm{N}$ \\
\hline Predicted Value & 1.53 & 3.81 & 2.73 & .655 & 56 \\
\hline Residual & -2.241 & 1.460 & .000 & .824 & 56 \\
\hline Std. Predicted Value & -1.839 & 1.648 & .000 & 1.000 & 56 \\
\hline Std. Residual & -2.668 & 1.738 & .000 & .982 & 56 \\
\hline
\end{tabular}

a. Dependent Variable: Extent artificial intelligence is being used in your company to automatically engage with candidates

\section{Observation:}

Significant Alpha vale p>0.05 for ANOVA and f-statistics indicates the rejection of null hypothesis which signifies that Artificial intelligence help in employee engagement.

\section{Findings and Conclusion}

1. Artificial Intelligence is a boon for HR managers with respect to Talent Management.

2. Artificial intelligence can contribute effectively in career path development of the employees in an organization

3. Artificial intelligence can help in employee engagement.

4. Use of artificial intelligence in HR management is still not so common as per the findings of this research.

5. Most of the HR managers acknowledge the use of artificial 
intelligence in their domain.

6. It is found that artificial intelligence can be an effective tool in talent acquisition based on job description, education and locality.

7. The use of artificial intelligence is justified by HR managers for talent acquisition.

8. Artificial intelligence is also found useful in performance management, automating screening and to reduce human bias during interviews.

9. Artificial intelligence is found helpful in guiding new recruiters through company policies.

10. Artificial intelligence is found helpful in performance management through timely performance appraisal.

11. Artificial intelligence is found helpful in effective career path development for employees according to this study.

\section{CONCLUSION}

From the research it can be safely concluded that Artificial intelligence is the need of the hour. Artificial intelligence is such a weapon which can help the HR managers in IT sector to become the most profit making and successful sector in the entire country. Artificial intelligence and HR can be a great help to the society. With the help of Artificial intelligence HR managers can get rid of repetitive work and can dedicate themselves more towards effective talent acquisition, performance management and career development for the employees. This process helps in increasing the employability and job satisfaction of the people who are hired. The hired people's status in the society increases and he or she gets a social recognition. More and more people become financially independent and this not only helps in individual and company growth but it also directly increases the financial growth of a country.

\section{SCOPE FOR FURTHER RESEARCH}

This paper is based basically on the benefit of artificial intelligence in talent management in HR. There are other sectors where artificial intelligence can be a boon for HR. In this paper employee engagement as one of the factors is being researched but emotional intelligence is not touched. Emotional intelligence and empathy is very essential for improving the job experience and increase in employee engagement of an employee. The future study can be based on emotional intelligence and empathy. Through emotional intelligence and empathy the HR manager can understand the mind set of employees much better and can retain the employees better. Another area which can be researched is increase in employability with the help of artificial intelligence as the future belongs to the fact that man and machine will work together and would make employability much better and higher.

\section{REFERENCES}

1. Acktar, Reese, Dave Winsborough, Uri Ort, Abigail Johnson, Tomas ChamorroPremuzic. 2018. Detercting the Dark Side of Personality Using Social Media. Personality and Individual Differences, 132:90-97.

2. Clemence R.V., (ed.) 2009, Essays on Entrepreneurship, Innovations, Business Cycles and the Evolution of the Capitalism, Joseph A. Schumpeter, Transaction Publishers, New Brunswick, New Jersey.

3. Cowgill, Bo (2017) The Labor Market Effects of Hiring through Machine Learning Working Paperowgill, Bo. 2018. "Bias and Productivity in
Humans and Algorithms. Theory and Evidence from Résumé Screening.” Working paper.

4. Dr. Aruna Deshpande, Talent Acquisition through Technology, IOSR Journal of Business and Management, e-ISSN: 2278-487X, p-ISSN: 2319-7668, 2018, PP 72-79.

5. Dr. Saundarya Rajesh, Ph.D, Mr. UmasankerKandaswamy, Ms. Anju Rakesh. "The impact of Artificial Intelligence in Talent Acquisition Lifecycle of organizations: A global perspective", International Journal of Engineering Development and Research (IJEDR), ISSN:2321-9939, Vol.6, Issue 2, pp.709-717, June 2018.

6. Eldho Jacob Joy, Arjun S Menon and Biju N, Multi-Modal Parameter Based Delamination Detection in Composite Structures Using Methods of Artificial Intelligence. International Journal of Civil Engineering and Technology, 8(8), 2017, pp. 1105-1113.

7. FREEMAN, C. 1987, Technology Policy and Economic Performance: Lessons from Japan, Frances Printer Publishers, London, New York.

8. Geetha R\&BhanuSree Reddy D, Recruitment Through Artificial Intelligence: A Conceptual Study, International Journal of Mechanical Engineering and Technology (IJMET), Volume 9, Issue 7, July 2018, pp. 63-70, Article ID: IJMET_09_07_007.

9. Holm, A., 2010. The effect of e-recruitment on the recruitment process: Evidence from case studies of three Danish MNCs. In Proceedings of the 3rd European academic workshop on electronic human resource management (pp. 91-111).

10. McCarthy, J., 1998. What is artificial intelligence?

11. Muthukumaran, C.K., 2014. Recruitment process: a study among the employees at information technology (it) industry in Chennai. International Journal of Management Research and Reviews, 4(1), p.91.

12. S. RinaMaiti and Dr. L. Mishra, GIS and Sensor Based Rain Water Harvesting with Artificial Intelligence System for Free Landsliding, International Journal of Civil Engineering and Technology, 9(6), 2018, pp. 54-66.

13. Schumpeter, J.A. 1942. Capitalism, Socialism and Democracy, 3rd edition, London: George Allen and Unwin, 1976.

14. Śledzik, Karol. (2013). Schumpeter's View on Innovation and Entrepreneurship. SSRN Electronic Journal. 10.2139/ssrn.2257783.

15. Srivastava, Sameer and Amir Goldberg. 2017. "Language as a Window into Culture." California Management Review 60(1): 56-69.

\section{AUTHORS PROFILE}

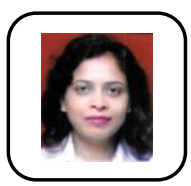

Dr. Reena (Mahapatra) Lenka has 10 years of teaching experience as an HR faculty in different MBA institutes and almost 10 years of industrial experience as an HR person. Is presently working as an Assistant professor $\mathrm{HR}$ in MITCOM under MIT ADT University, Pune. Has 6 Publications to my credit in HR stream. She has also attended 2 International conferences. Educational qualification: $\mathrm{PhD}(\mathrm{HR})$ MBA (HR), PGBDM (Marketing) and B.Sc. (Bio-science).

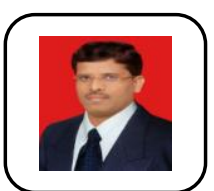

Dr. Anand B. Dadas, (M.B.A., M.P.M., M.Com. M.Sc., DLL\&LW, M.Phil., Ph.D.) Presently, working as Director and Professor, Neville Wadia Institute of Management Studies \& Research. Currently, he is a chairman of Board of Studies (HRM) and a Member of Academic Council, Savitribai Phule Pune University, Pune. He has 22 years of experience, 45 Publications in Journals and Proceedings, 11 Books published. He has Guided 5 Ph.D. scholars for their Doctoral Degree and 200 M.B.A. Graduates for their academic projects. He has been serving as an Editor, Reviewer and Board member for 7 Research Journals and principal investigator for UGC and BCUD, Savitribai Phule Pune University research projects. 